\title{
PAP SMEAR AND CHLAMYDIA
}

\author{
Viroj WIWANITKIT \\ Wiwanitkit House, Bangkhae, Bangkok, Thailand \\ Received in September 2009 \\ Accepted in November 2009
}

I have read the recent publication by Ujević et al. with great interest (1). The authors concluded that "Pap smear was not specific enough to demonstrate chlamydial infection (1)". Indeed, the high prevalence of chlamydial infection among working women has been confirmed in several settings around the world. Pap smear is a recommended routine test for these working women. However, there have been reports of problematic screening for microorganisms, not only for Chlamydia spp, with pap smear (2). Several new attempts have been made to cope with this problem. For chlamydial infection, there are several new alternatives including a PCR-based test and ThinPrep pap test with confirmed good diagnostic properties (34). Application of these new tests in working women should be based on cost effectiveness.

\section{REFERENCES}

1. Ujević B, Habek JC, Habek D. Prevalence of Infection with Neisseria gonorrhoeae or Chlamydia trachomatis in acute mucopurulent cervicitis. Arh Hig Rada Toksikol 2009;60:197-203.

2. Fitzhugh VA, Heller DS. Significance of a diagnosis of microorganisms on pap smear. J Low Genit Tract Dis 2008;12:40-51.

3. Scimia M. ThinPrep pap test: a platform for gynecological diagnosis. Adv Clin Pathol 2001;5:183-4.

4. Taylor-Robinson D, Thomas BJ. Laboratory techniques for the diagnosis of chlamydial infections. Genitourin Med 1991;67:256-66.

\section{CORRESPONDING AUTHOR:}

Professor Viroj Wiwanitkit Wiwanitkit House, Bangkhae, Bangkok Thailand 10160

E-mail:wviroj@yahoo.com 